CIVIL AND ENVIRONMENTAL ENGINEERING REPORTS

E-ISSN 2450-8594

CEER 2018; 28 (3): 121-131

DOI: $10.2478 /$ ceer-2018-0040

Original Research Article

\title{
EFFICIENCY OF SEWAGE TREATMENT PLANTS IN THE SEQUENTIAL BATCH REACTOR
}

\author{
Anita JAKUBASZEK ${ }^{1}$, Artur STADNIK ${ }^{2}$ \\ University of Zielona Góra, Poland
}

\begin{abstract}
The article analyzes the effectiveness of individual Actibloc wastewater treatment plants (produced by Sotralentz) working in the technology of low-rate activated sludge in the Sequential Batch Reactor (SBR) system. The assessment of the effectiveness of household wastewater treatment plants was made on the basis of pollutants: $\mathrm{BOD}_{5}$, COD, total suspended solids, total nitrogen and total phosphorus. The research objects were four household sewage treatment plants located in: Lubań, Kłębanowice, Stara Rzeka and Kościan. The efficiency of removing pollutants in the examined facilities was in the range of: $\mathrm{BOD}_{5} 92.2 \div 97.2 \%$, COD $82.6 \div 89.9 \%$, total suspended solids $90.2 \div$ $96.2 \%$, total nitrogen $50.8 \div 83.1 \%$, total phosphorus $46.5 \div 73.6 \%$. The treated wastewater met the requirements set out in the Regulation of the Minister of the Environment on the conditions to be met when discharging sewage into water or soil, and on substances particularly harmful to the aquatic environment (Journal of Laws 2014, item 1800) in terms of indicators such as $\mathrm{BOD}_{5}$, COD, total suspended solids and total nitrogen. The effectiveness of phosphorus removal in the studied treatment plants was much lower.
\end{abstract}

${ }^{1}$ Corresponding author: University of Zielona Gora, Institute of Environmental Engineering, ul. Szafrana 15, 65-246 Zielona Góra, Poland; e-mail: a.jakubaszek@iis.uz.zgora.pl, tel. +48683282396

${ }^{2} \mathrm{PhD}$ Student of the University of Zielona Góra, Poland 
Keywords: individual sewage treatment systems, sequencing batch reactor, monitoring, efficiency

\section{INTRODUCTION}

Habitants of non-canalised areas use onsite sewage collection systems: holding tanks and onsite wastewater treatment systems. For the last few years, a systematic decrease of holding tanks number has been noted, with simultaneous increase of onsite wastewater treatment systems number. Number of holding tanks decreased from about 2,136 thousands in 2015 to 2,117 thousands in 2016 (by $0.9 \%$ ), while number of onsite wastewater treatment systems increased from about 203 thousands in 2015 to about 217 thousands in $2016[2,6]$.

Domestic wastewater treatment plants provide an opportunity to curb illegal discharges of untreated wastewater into the environment.

Activated sludge is a popular and effective method of wastewater treatment, however, the technology has certain requirements which must be met to ensure proper removal of organic compounds, nitrogen, and phosphorus, which is more and more frequently required also in small systems $[3,8]$.

The optimal solution for the management of waste water from individual farms is the SBR system. Such systems are less sensitive to unfavorable working conditions, more resistant to hydraulic overloads and varying amounts of wastewater inflow [4,7].

SBR plants have many advantages that make them a competitive solution in relation to classical activated sludge flow systems [4,5]. These are, first and foremost:

- greater flexibility of system operation, possibility of quick parameter changes depending on the amount and constitution of incoming sewage,

- high resistance to uneven inflow of sewage and changes in pollution loads, smaller reactor volumes needed for wastewater treatment processes,

- possibility of precise maintenance of a fixed age of sludge - basic technological parameter of a treatment plant with active sludge,

- lack of secondary settling tanks,

- automatic control of reactors.

It is advisable to use SBR reactors wherever there are significant fluctuations in the amount of wastewater and rapid changes in the concentration of pollutants in incoming wastewater. Due to the cyclical nature of technological operations and batch discharge of waste water, these plants are highly effective in removing contaminants and are characterized by high resistance to hydraulic and substrate loads. 
The aim of the study was to assess the work and analyze the effectiveness of pollution removal in domestic SBR wastewater treatment plants of Actibloc type.

\section{MATERIAL AND METHODS}

The research objects were four Actibloc (produced by Sotralentz) backyard sewage treatment plants operating in the low-load sludge technology in the SBR system. The throughput of the studied objects ranged from 0.6 to $1.8 \mathrm{~m}^{3} / \mathrm{d}$ (Tab. 1).

Three wastewater treatment plants operate near residential buildings, while the wastewater treatment plant in Kościan near the workplace, which receives only domestic wastewater from sanitary rooms and kitchens for employees. Wastewater inflowing to the tested systems was characterized by typical parameters for household wastewater. The inflow of wastewater to the treatment plant was uneven. The largest performance took place in the morning (morning toilet) and late afternoon and evening (evening toilet).

The analysed wastewater treatment plants were installed and put into operation in years: 2012 - sewage treatment plant in Kościan, 2013 - installations in Lubań and Kłebanowice and 2014 - a sewage treatment plant in the Stara Rzeka. The installations are exploited by the users in accordance with the operating manual and are covered by the manufacturer's cyclical factory service.

Table 1. Basic technological data of Actibloc SBR systems

\begin{tabular}{|l|c|c|c|c|c|}
\hline \multicolumn{1}{|c|}{ Location } & $\begin{array}{c}\text { Wastewater } \\
\text { treatment } \\
\text { plant }\end{array}$ & $\begin{array}{c}\text { Flow } \\
\left(\mathrm{m}^{3} / \mathrm{d}\right)\end{array}$ & $\begin{array}{c}\text { Loading of organic } \\
\text { substances }(\mathrm{kg} \mathrm{BOD} / \mathrm{d})\end{array}$ & $\begin{array}{c}\text { Vollume of } \\
\text { the settler } \\
\left(\mathrm{m}^{3}\right)\end{array}$ & $\begin{array}{c}\text { Bioreactor } \\
\text { volume } \\
\left(\mathrm{m}^{3}\right)\end{array}$ \\
\hline Lubań & Actibloc 4 & 0.6 & 0.30 & 2.5 & 2.5 \\
\hline Stara Rzeka & Actibloc 4 & 0.6 & 0.30 & 2.5 & 2.5 \\
\hline Kłębanowice & Actibloc 5-6 & 0.9 & 0.36 & 3.5 & 2.5 \\
\hline Kościan & Actibloc 7-8 & 1.8 & 0.48 & 3.5 & 3.5 \\
\hline
\end{tabular}

Actibloc wastewater treatment plants consist of two tanks made of PEHD: a primary settling tank and SBR bioreactor and a technical box with a control system and a membrane blower. The reactor is equipped with a fine bubble diaphragm diffuser and two mammoth pumps: the first one pumps the treated wastewater to the receiver, the second one is used for sludge recirculation.

The system is operated in four six-hour cycles per day. The complete treatment cycle was divided into five consecutive phases: filling (approx. $10 \mathrm{~min}$.), aeration (approx. $248 \mathrm{~min}$.), sedimentation (approx. $90 \mathrm{~min}$.), decantation 
(approx. 10 min.) and recirculation (approx. $1 \mathrm{~min}$.). In individual phases, the individual processes of removing pollutants from waste water take place successively, with the maintenance of variable aerobic and anaerobic conditions. The receivers of wastewater treated in Lubań and the Stara Rzeka are lymphatic wells, while in Kłębanowice and Kościan - draining.

Sampling was carried out four times a year in January, May, August and November at each of the treatment plants tested. Raw sewage samples were taken at the inflow to the primary settling tanks, while treated sewage from the outflow of the treatment plant was taken from the sampling well.

Wastewater samples were taken in accordance with PN-ISO 5667-10:1997. $\mathrm{BOD}_{5}$ (respirometric method), COD, total suspended solids (direct weight method), nitrogen and total phosphorus were determined in samples of raw and treated wastewater according to the current methodology. The results have been used to calculate the effectiveness of the removal of pollutants from waste water.

\section{RESULTS AND DISSCUSION}

Test results of raw and treated wastewater samples taken from the analysed wastewater treatment plants are presented in Tables from 2 to 5 .

During the research period, the lowest wastewater temperatures were recorded in January and November, ranging from 11.5 to $17.0^{\circ} \mathrm{C}$. The highest in summer, May and August and ranged from 17.5 to $19.5^{\circ} \mathrm{C}$.

In all examined objects the $\mathrm{pH}$ of wastewater remained at the level of 7.0 to 7.5 in wastewater inflowing to the treatment plant and 7.1 to 7.5 in treated wastewater.

The raw sewage flowing into the tested treatment plants was characterized by an uneven quality composition. $\mathrm{BOD}_{5}$ in raw sewage ranged from 408 to 889 $\mathrm{mgO}_{2} / \mathrm{dm}^{3}$ (mean $513.8 \mathrm{mgO}_{2} / \mathrm{dm}^{3}$ ), and in treated sewage from 12 to 69 $\mathrm{mgO}_{2} / \mathrm{dm}^{3}$ (mean $23.1 \mathrm{mgO}_{2} / \mathrm{dm}^{3}$ ). The maximum values for each treatment plant are shown in Tables from 2 to 5 .

The content of organic pollutants expressed as COD in the raw sewage was in the range from 810 to $1310 \mathrm{mgO}_{2} / \mathrm{dm}^{3}$ (mean $910.3 \mathrm{mgO}_{2} / \mathrm{dm}^{3}$ ). In treated wastewater, COD values ranged from 85 to $188 \mathrm{mg} / \mathrm{dm}^{3}$ (mean 116.3 $\mathrm{mgO}_{2} / \mathrm{dm}^{3}$ ).

In the studied objects the content of total suspended solids in raw wastewater varied from 370 to $560 \mathrm{mg} / \mathrm{dm}^{3}$ (mean $454.0 \mathrm{mg} / \mathrm{dm}^{3}$ ), and in treated sewage from 17 to $55 \mathrm{mg} / \mathrm{dm}^{3}$ (mean $27.5 \mathrm{mg} / \mathrm{dm}^{3}$ ).

In the study period under review total nitrogen content in raw sewage ranged from 42 to $71 \mathrm{mgN} / \mathrm{dm}^{3}$ (mean $59.4 \mathrm{mgN} / \mathrm{dm}^{3}$ ). In the treated sewage the total nitrogen concentration was in the range of $12 \div 31 \mathrm{mgN} / \mathrm{dm}^{3}$ (mean 16.1 $\mathrm{mgN} / \mathrm{dm}^{3}$ ). 
The amount of total phosphorus in raw sewage varied in the range from 8.2 to $14.0 \mathrm{mgP} / \mathrm{dm}^{3}$ (mean: $11.4 \mathrm{mgP} / \mathrm{dm}^{3}$ ). The effluent contained from 2.9 to 6.4 $\mathrm{mgP} / \mathrm{dm}^{3}$ (mean: $4.9 \mathrm{mgP} / \mathrm{dm}^{3}$ ).

Table 2. Parameters of raw and treated wastewater - SBR system in Lubań

\begin{tabular}{|l|c|c|c|c|c|c|c|c|}
\hline & \multicolumn{2}{|c|}{ January } & \multicolumn{2}{c|}{ May } & \multicolumn{2}{c|}{ August } & \multicolumn{2}{c|}{ November } \\
\cline { 2 - 9 } & $\begin{array}{c}\text { Raw } \\
\text { wastewater }\end{array}$ & $\begin{array}{c}\text { Treated } \\
\text { wastewater }\end{array}$ & $\begin{array}{c}\text { Raw } \\
\text { wastewater }\end{array}$ & $\begin{array}{c}\text { Treated } \\
\text { wastewater }\end{array}$ & $\begin{array}{c}\text { Raw } \\
\text { wastewater }\end{array}$ & $\begin{array}{c}\text { Treated } \\
\text { wastewater }\end{array}$ & $\begin{array}{c}\text { Raw } \\
\text { wastewater }\end{array}$ & $\begin{array}{c}\text { Treated } \\
\text { wastewater }\end{array}$ \\
\hline $\mathrm{pH}$ & 7.2 & 7.1 & 7.2 & 7.1 & 7.2 & 7.1 & 7.1 & 7.2 \\
\hline $\begin{array}{l}\text { Temperature } \\
{\left[{ }^{\circ} \mathrm{C}\right]}\end{array}$ & 12.5 & 12.5 & 17.7 & 17.8 & 18.6 & 18.2 & 16.5 & 16.5 \\
\hline $\begin{array}{l}\mathrm{BOD}_{5} \\
{\left[\mathrm{mgO}_{2} / \mathrm{dm}^{3}\right]}\end{array}$ & 570 & 19 & 475 & 15 & $\mathbf{8 8 9}$ & $\mathbf{6 9}$ & 540 & 24 \\
\hline $\begin{array}{l}\mathrm{COD} \\
{\left[\mathrm{mgO}_{2} / \mathrm{dm}^{3}\right]}\end{array}$ & 901 & 115 & 950 & 105 & $\mathbf{1 3 1 0}$ & $\mathbf{1 8 8}$ & 895 & 125 \\
\hline $\begin{array}{l}\mathrm{TSS} \\
{\left[\mathrm{mg}_{\left.\mathrm{dm}^{3}\right]}\right]}\end{array}$ & 459 & 25 & 500 & 19 & $\mathbf{5 6 0}$ & $\mathbf{5 5}$ & 430 & 27 \\
\hline $\begin{array}{l}\mathrm{N}_{\text {tot }} \\
{\left[\mathrm{mgN} / \mathrm{dm}^{3}\right]}\end{array}$ & 61 & 18 & 48 & 12 & $\mathbf{6 3}$ & $\mathbf{3 1}$ & 56 & 13 \\
\hline $\begin{array}{l}\mathrm{P}_{\text {tot }} \\
{\left[\mathrm{mgP} / \mathrm{dm}^{3}\right]}\end{array}$ & $\mathbf{1 3 . 0}$ & 5.5 & 11.0 & 2.9 & 11.2 & 4.5 & 12.0 & $\mathbf{6 . 2}$ \\
\hline
\end{tabular}

Table 3. Parameters of raw and treated wastewater - SBR system in Kłębanowice

\begin{tabular}{|l|c|c|c|c|c|c|c|c|}
\hline & \multicolumn{2}{|c|}{ January } & \multicolumn{2}{c|}{ May } & \multicolumn{2}{c|}{ August } & \multicolumn{2}{c|}{ November } \\
\cline { 2 - 9 } & $\begin{array}{c}\text { Raw } \\
\text { wastewater }\end{array}$ & $\begin{array}{c}\text { Treated } \\
\text { wastewater }\end{array}$ & $\begin{array}{c}\text { Raw } \\
\text { wastewater }\end{array}$ & $\begin{array}{c}\text { Treated } \\
\text { wastewater }\end{array}$ & $\begin{array}{c}\text { Raw } \\
\text { wastewater }\end{array}$ & $\begin{array}{c}\text { Treated } \\
\text { wastewater }\end{array}$ & $\begin{array}{c}\text { Raw } \\
\text { wastewater }\end{array}$ & $\begin{array}{c}\text { Treated } \\
\text { wastewater }\end{array}$ \\
\hline $\mathrm{pH}$ & 7.0 & 7.1 & 7.2 & 7.1 & 7.1 & 7.1 & 7.2 & 7.2 \\
\hline $\begin{array}{l}\text { Temperature } \\
{\left[{ }^{\circ} \mathrm{C}\right]}\end{array}$ & 11.5 & 11.7 & 18.3 & 18.0 & 18.0 & 18.1 & 17.5 & 17.3 \\
\hline $\begin{array}{l}\mathrm{BOD} 5 \\
{\left[\mathrm{mgO}_{2} / \mathrm{dm}^{3}\right]}\end{array}$ & 408 & $\mathbf{2 6}$ & 430 & 22 & $\mathbf{6 7 6}$ & $\mathbf{2 6}$ & 450 & 24 \\
\hline $\begin{array}{l}\mathrm{COD} \\
{\left[\mathrm{mgO}_{2} / \mathrm{dm}^{3}\right]}\end{array}$ & 810 & 89 & 845 & 85 & $\mathbf{9 5 4}$ & $\mathbf{1 4 1}$ & 830 & 115 \\
\hline $\begin{array}{l}\mathrm{TSS} \\
{\left[\mathrm{mg} / \mathrm{dm}^{3}\right]}\end{array}$ & 470 & $\mathbf{3 5}$ & 399 & 24 & $\mathbf{5 0 1}$ & 31 & 430 & 30 \\
\hline $\begin{array}{l}\mathrm{N}_{\text {tot }} \\
{\left[\mathrm{mgN} / \mathrm{dm}^{3}\right]}\end{array}$ & $\mathbf{6 5}$ & $\mathbf{2 0}$ & 52 & 14 & 64 & 12 & 60 & 15 \\
\hline $\begin{array}{l}\mathrm{P}_{\text {tot }} \\
{\left[\mathrm{mgP} / \mathrm{dm}^{3}\right]}\end{array}$ & 9.9 & 5.3 & $\mathbf{1 2 . 5}$ & 4.4 & 12.0 & $\mathbf{6 . 4}$ & 8.8 & 4.3 \\
\hline
\end{tabular}


Table 4. Parameters of raw and treated wastewater - SBR system in Stara Rzeka

\begin{tabular}{|l|c|c|c|c|c|c|c|c|}
\hline & \multicolumn{2}{|c|}{ January } & \multicolumn{2}{c|}{ May } & \multicolumn{2}{c|}{ August } & \multicolumn{2}{c|}{ November } \\
\cline { 2 - 9 } & $\begin{array}{c}\text { Raw } \\
\text { wastewater }\end{array}$ & $\begin{array}{c}\text { Treated } \\
\text { wastewater }\end{array}$ & $\begin{array}{c}\text { Raw } \\
\text { wastewater }\end{array}$ & $\begin{array}{c}\text { Treated } \\
\text { wastewater }\end{array}$ & $\begin{array}{c}\text { Raw } \\
\text { wastewater }\end{array}$ & $\begin{array}{c}\text { Treated } \\
\text { wastewater }\end{array}$ & $\begin{array}{c}\text { Raw } \\
\text { wastewater }\end{array}$ & $\begin{array}{c}\text { Treated } \\
\text { wastewater }\end{array}$ \\
\hline $\mathrm{pH}$ & 7.3 & 7.3 & 7.1 & 7.1 & 7.3 & 7.2 & 7.2 & 7.1 \\
\hline $\begin{array}{l}\text { Temperature } \\
{\left[{ }^{\circ} \mathrm{C}\right]}\end{array}$ & 12.9 & 13 & 18.2 & 17.9 & 19 & 19.3 & 16.4 & 15.8 \\
\hline $\begin{array}{l}\mathrm{BOD} \\
{\left[\mathrm{mgO}_{2} / \mathrm{dm}^{3}\right]}\end{array}$ & 450 & 16 & 471 & 17 & 507 & 14 & $\mathbf{5 2 0}$ & $\mathbf{1 9}$ \\
\hline $\begin{array}{l}\mathrm{COD} \\
{\left[\mathrm{mgO}_{2} / \mathrm{dm}^{3}\right]}\end{array}$ & 810 & $\mathbf{1 4 1}$ & 842 & 95 & 900 & 115 & $\mathbf{9 1 1}$ & 101 \\
\hline $\begin{array}{l}\mathrm{TSS} \\
{\left[\mathrm{mg} / \mathrm{dm}^{3}\right]}\end{array}$ & $\mathbf{5 0 1}$ & 26 & 489 & 21 & 410 & 25 & 399 & $\mathbf{2 7}$ \\
\hline $\begin{array}{l}\mathrm{N}_{\text {tot }} \\
{\left[\mathrm{mgN} / \mathrm{dm}^{3}\right]}\end{array}$ & $\mathbf{6 4}$ & $\mathbf{2 0}$ & 42 & 14 & 56 & 14 & 58 & 15 \\
\hline $\begin{array}{l}\mathrm{P}_{\text {tot }} \\
{\left[\mathrm{mgP} / \mathrm{dm}^{3}\right]}\end{array}$ & $\mathbf{1 1 . 8}$ & 5.0 & 11.0 & $\mathbf{5 . 1}$ & 9.9 & $\mathbf{5 . 1}$ & 8.2 & 3.9 \\
\hline
\end{tabular}

Table 5. Parameters of raw and treated wastewater - SBR system in Kościan

\begin{tabular}{|l|c|c|c|c|c|c|c|c|}
\hline & \multicolumn{2}{|c|}{ January } & \multicolumn{2}{c|}{ May } & \multicolumn{2}{c|}{ August } & \multicolumn{2}{c|}{ November } \\
\cline { 2 - 9 } & $\begin{array}{c}\text { Raw } \\
\text { wastewater }\end{array}$ & $\begin{array}{c}\text { Treated } \\
\text { wastewater }\end{array}$ & $\begin{array}{c}\text { Raw } \\
\text { wastewater }\end{array}$ & $\begin{array}{c}\text { Treated } \\
\text { wastewater }\end{array}$ & $\begin{array}{c}\text { Raw } \\
\text { wastewater }\end{array}$ & $\begin{array}{c}\text { Treated } \\
\text { wastewater }\end{array}$ & $\begin{array}{c}\text { Raw } \\
\text { wastewater }\end{array}$ & $\begin{array}{c}\text { Treated } \\
\text { wastewater }\end{array}$ \\
\hline $\mathrm{pH}$ & 7.5 & 7.5 & 7.1 & 7.1 & 7 & 7.1 & 7.1 & 18 \\
\hline $\begin{array}{l}\text { Temperature } \\
{\left[{ }^{\circ} \mathrm{C}\right]}\end{array}$ & 12.5 & 12.7 & 17.3 & 17 & 19.5 & 19 & 18 & 16 \\
\hline $\begin{array}{l}\mathrm{BOD} \\
{\left[\mathrm{mgO}_{2} / \mathrm{dm}^{3}\right]}\end{array}$ & 414 & 12 & $\mathbf{5 1 1}$ & $\mathbf{2 5}$ & 450 & $\mathbf{2 5}$ & 459 & 16 \\
\hline $\begin{array}{l}\mathrm{COD} \\
{\left[\mathrm{mgO} / \mathrm{dm}^{3}\right]}\end{array}$ & $\mathbf{9 5 0}$ & 119 & 891 & 95 & 885 & 112 & 880 & $\mathbf{1 2 0}$ \\
\hline $\begin{array}{l}\mathrm{TSS} \\
{\left[\mathrm{mg} / \mathrm{dm}^{3}\right]}\end{array}$ & 467 & $\mathbf{3 2}$ & 370 & 17 & $\mathbf{4 8 0}$ & 25 & 399 & 21 \\
\hline $\begin{array}{l}\mathrm{N}_{\text {tot }} \\
{\left[\mathrm{mgN} / \mathrm{dm}^{3}\right]}\end{array}$ & 70 & 12 & 59 & 14 & $\mathbf{7 1}$ & 12 & 61 & $\mathbf{2 1}$ \\
\hline $\begin{array}{l}\mathrm{P}_{\text {tot }} \\
{\left[\mathrm{mgP} / \mathrm{dm}^{3}\right]}\end{array}$ & 11.8 & 4.0 & $\mathbf{1 4 . 0}$ & 5.0 & 13.0 & $\mathbf{6 . 0}$ & 12.8 & 5.1 \\
\hline
\end{tabular}

The removal efficiency of organic pollutants, expressed by $\mathrm{BOD}_{5}$, in the studied objects varied between 92.2 and $97.2 \%$ (Fig. 1). In the study period under consideration, the highest average efficiency of $\mathrm{BOD}_{5}$ reduction was achieved at the Stara Rzeka treatment plant, which was $96.6 \%$. The values of $\mathrm{BOD}_{5}$ in treated wastewater in all systems were lower than $40 \mathrm{mgO}_{2} / \mathrm{dm}^{3}$, which is required in accordance with the Regulation of the Minister of the Environment on the conditions to be met when discharging sewage into water or soil, and on substances particularly harmful to the aquatic environment (Journal of Laws 2014, item 1800) [9]. Only at the Lubań WWTP, this value was exceeded once (in August). 


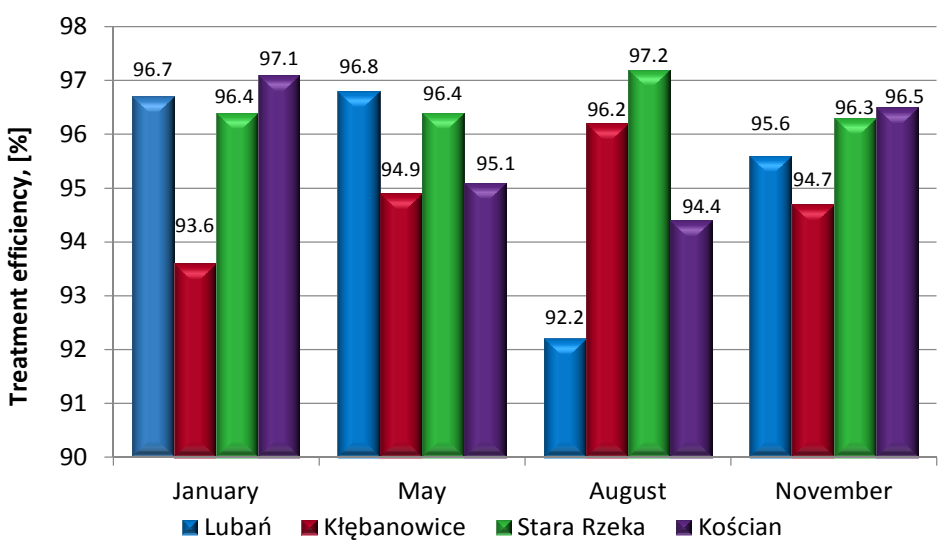

Fig. 1. Efficiency of $\mathrm{BOD}_{5}$ removal

The effectiveness of COD reduction ranged from 82.6 to $89.9 \%$ (Fig. 2). The highest average COD removal efficiency of $87.6 \%$ was recorded at the Kłębanowice and Kościan WWTPs. In accordance with the requirements [Journal of Laws 2014, item 1800] the COD in treated wastewater should be less than $150 \mathrm{mgO}_{2} / \mathrm{dm}^{3}$. At the Luban WWTP this value was exceeded in August and was $188 \mathrm{mgO}_{2} / \mathrm{dm}^{3}$. The content of organic pollutants expressed through COD in the remaining samples of treated wastewater was below the acceptable value.

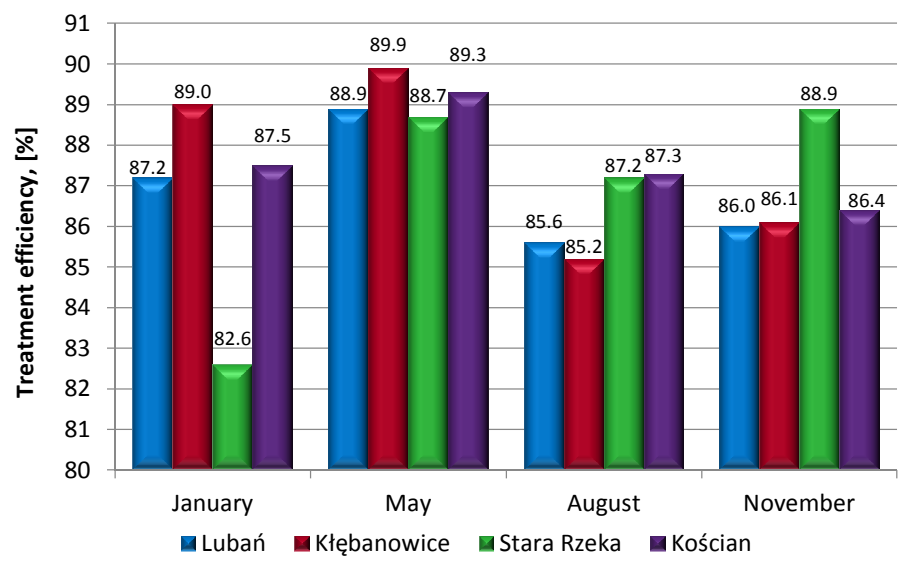

Fig. 2. Efficiency of COD removal 
The removal efficiency of the total suspended solids was high and ranged from 90.2 to $96.2 \%$ (Fig. 3). The wastewater treatment plant in Kościan was characterized by the highest average efficiency of reducing the concentration of total suspended solids in wastewater $-94.5 \%$. According to the Regulation of the Minister of the Environment on the conditions to be met when discharging sewage into water or soil, and on substances particularly harmful to the aquatic environment (Journal of Laws 2014, item 1800), the concentration of the total suspended solids in wastewater discharged from treatment plants below 2000 p.e. should not exceed $50 \mathrm{mg} / \mathrm{dm}^{3}$. The examined wastewater treatment plants operated steadily and the amount of total suspended solids in the treated wastewater was within the range required by the ordinance. In August, the concentration of total suspended solids in the treated wastewater was higher at $55 \mathrm{mg} / \mathrm{dm}^{3}$ at the Lubań treatment plant.

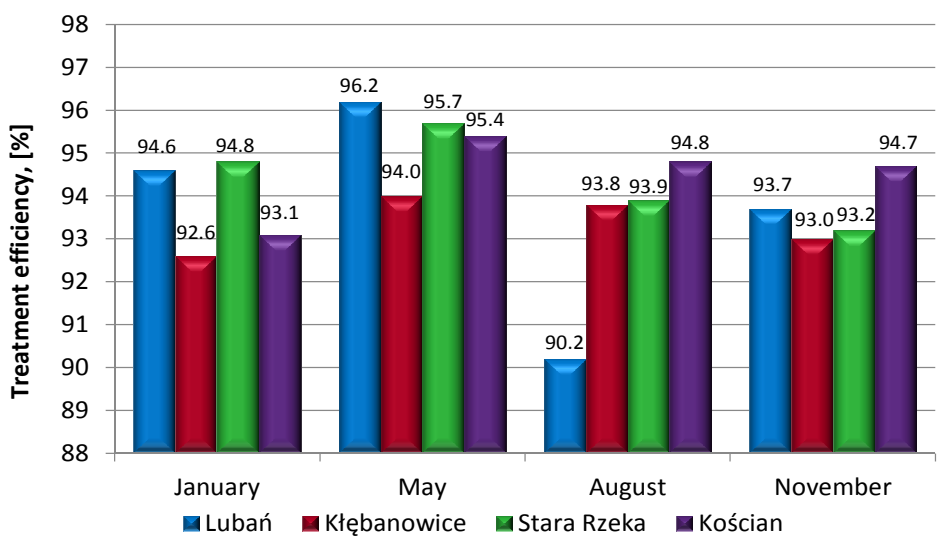

Fig. 3. Efficiency of removing the total suspension solids

In wastewater treatment plants of less than 2000 p.e. nitrogen and total phosphorus concentrations shall be standardised only if the treated wastewater is discharged into lakes and their tributaries, directly into artificial waters and agglomerations. The amount of total nitrogen in the treated wastewater should not exceed $30 \mathrm{mgN} / \mathrm{dm}^{3}$ and total phosphorus $5 \mathrm{mgP} / \mathrm{dm}^{3}$. 


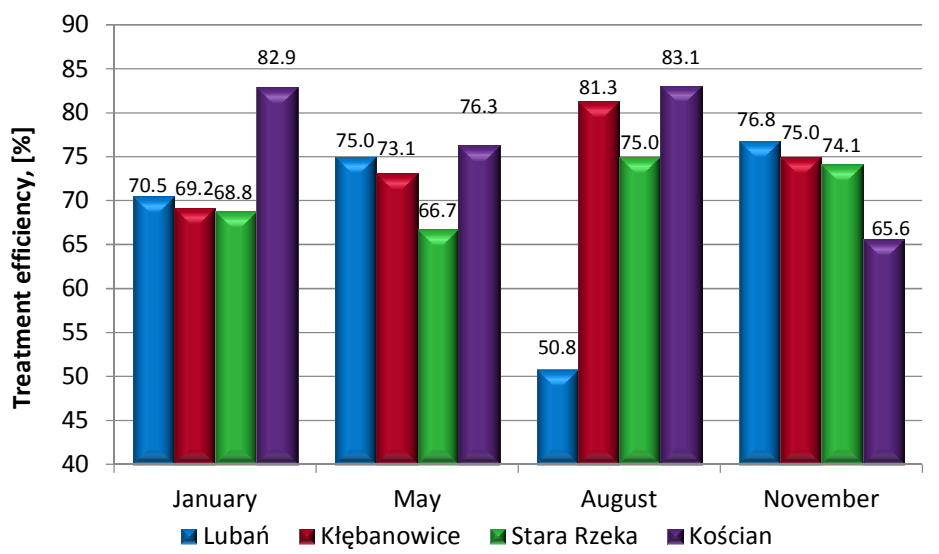

Fig. 4. Efficiency of total nitrogen removal

The effectiveness of total nitrogen removal in the studied facilities ranged from 50.8 to $83.1 \%$ (Fig. 4). The highest average nitrogen removal efficiency was achieved at the Kościan treatment plant at $77.0 \%$. Reffering to the level required by the Regulation, in the tested treatment plants only at the Luban treatment plant in August, a slightly higher concentration of total nitrogen in treated wastewater was recorded, amounting to $31.0 \mathrm{mgN} / \mathrm{dm}^{3}$. In other samples of treated wastewater, the total nitrogen content did not exceed $20 \mathrm{mgN} / \mathrm{dm}^{3}$.

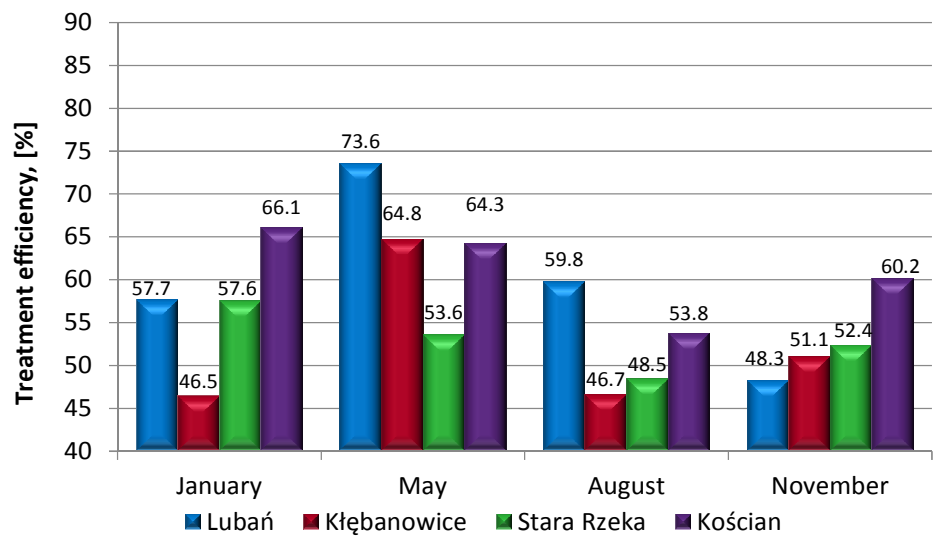

Fig. 5. Efficiency of total phosphorus removal

The effectiveness in removing total phosphorus from waste water over the period considered ranged from 46.5 to $73.6 \%$ (Fig. 5). The best results were achieved in the sewage treatment plant in Kościan, where the average removal efficiency was $61.1 \%$. In purified wastewater, concentrations of total phosphorus 
were high, in six samples they exceeded the permitted value of $5 \mathrm{mgP} / \mathrm{dm}^{3}$. According to Błażejewski [1], phosphorus removal in SBR treatment plants to below $5 \mathrm{mgP} / \mathrm{dm}^{3}$ is only possible with the use of the chemical precipitation module.

\section{CONCLUSIONS}

The overall assessment of the research results shows that individual installations operating in the SBR system are a very good and effective solution. The proper functioning of individual systems also depends to a large extent on the proper exploitation and maintenance of the system.

- The efficiency of removing pollutants in the examined facilities was in the range of: $\mathrm{BOD}_{5}$ from 92.2 to $97.2 \%$, COD from 82.6 to $89.9 \%$, total suspended solids from 90.2 to $96.2 \%$, total nitrogen from 50.8 to $83.1 \%$, total phosphorus from 46.5 to $73.6 \%$.

- The treatment plant in Kościan was characterized by the highest efficiency of removal of pollutants from sewage, where the average efficiency of removal of indicators was: $\mathrm{BOD}_{5} 95.8 \%$, COD $87.6 \%$, total suspended solids $94.5 \%$, total nitrogen $77.0 \%$, total phosphorus $61.1 \%$.

- The treated wastewater met the requirements set out in the Regulation of the Minister of the Environment on the conditions to be met when discharging sewage into water or soil, and on substances particularly harmful to the aquatic environment (Journal of Laws 2014, item 1800) in terms of indicators such as $\mathrm{BOD}_{5}, \mathrm{COD}$, total suspended solids and total nitrogen. The effectiveness of phosphorus removal in the studied treatment plants was much lower.

\section{REFERENCES}

1. Błażejewski R.: Kanalizacja wsi, Polskie Zrzeszenie Inżynierów i Techników Sanitarnych, Poznań 2003.

2. GUS 2017: Infrastruktura komunalna $w 2016 r$.

3. Heindrich Z. i in.: Leksykon Przydomowych oczyszczalni ścieków, Wydawnictwo Seidel-Przywecki, Warszawa 2013.

4. Jakubaszek A., Stadnik A., 2018: Technical and technological analisys of individual wastewater treatment systems, Civil and Enviromental Engineering Reports, 28 (1), 087-099

5. Makowska M., Sowińska A., 2014: Wykorzystanie reaktora porcjowego (SBR) $w$ indywidualnym systemie oczyszczania ścieków, Nauka Przyroda Technologie, dział Melioracje i Inżynieria Środowiska, 8, 29-47. 
6. Ministerstwo Środowiska, Aktualizacja Krajowego Programu Oczyszczania Ścieków Komunalnych, Warszawa (2017).

7. Myszograj S., Bydałek F., 2016: Temperature impact of nitrogen transformation in technological system: vertical flow constructed wetland and polishing pond, Civil and Enviromental Engineering Reports, 23 (4), 125-136.

8. PN EN 12566-1:2016-10, Małe oczyszczalnie ścieków dla obliczeniowej liczby mieszkańców (OLM) 50. Część 1: Prefabrykowane osadniki gnilne.

9. Rozporządzenie Ministra Środowiska z dnia 18 listopada 2014r. w sprawie warunków, jakie należy spełnić przy wprowadzaniu ścieków do wód lub do ziemi, oraz w sprawie substancji szczególnie szkodliwych dla środowiska wodnego (Dz. U. 2014 poz. 1800).

\title{
EFEKTYWNOŚĆ OCZYSZCZANIA ŚCIEKÓW W SEKWENCYJNYCH REAKTORACH BIOLOGICZNYCH
}

\begin{abstract}
Streszczenie
W artykule dokonano analizy efektywności funkcjonowania indywidualnych oczyszczalni ścieków Actibloc (producent: Sotralentz) pracujących w technologii niskoobciążonego osadu czynnego w systemie SBR. Oceny skuteczności pracy przydomowych oczyszczalni dokonano na podstawie badań wskaźników zanieczyszczeń: $\mathrm{BZT}_{5}$, ChZT, zawiesiny ogólnej, azotu ogólnego i fosforu ogólnego. Obiektami badań były cztery przydomowe oczyszczalnie ścieków zlokalizowane w miejscowościach: Lubań, Kłębanowice, Stara Rzeka i Kościan. Efektywność usuwania zanieczyszczeń w badanych obiektach była w zakresie: BZT $_{5} 92.2 \div 97.2 \%$, ChZT- $82.6 \div 89.9 \%$, zawiesina ogólna $-90.2 \div 96.2 \%$, azot ogólny $-50.8 \div 83.1 \%$, fosfor ogólny $-46.5 \div 73.6 \%$. Ścieki oczyszczone spełniały wymagania określone w Rozporządzeniu Ministra Środowiska w sprawie warunków, jakie należy spełnić przy wprowadzaniu ścieków do wód lub do ziemi, oraz w sprawie substancji szczególnie szkodliwych dla środowiska wodnego (Dz. U. 2014 poz. 1800) w zakresie wskaźników takich jak: BZT ${ }_{5}$, ChZT, zawiesiny ogólnej i azotu ogólnego. Skuteczność usuwania fosforu ogólnego w badanych oczyszczalniach była zdecydowanie niższa.
\end{abstract}

Słowa kluczowe: indywidualne systemy oczyszczania ścieków, sekwencyjny reaktor biologiczny, monitoring, wydajność

Editor received the manuscript 16.09.2018 